\title{
Orphanhood as Genesis in Miguel Delibes's La sombra del ciprés es alargada
}

Jeremy Squires

University College, Dublin

La sombra del ciprés es alargada (1948) won the prestigious Premio Eugenio Nadal in 1947 and launched the literary career of Miguel Delibes yet, despite its impressive debut, the quality and significance of this rather gloomy work have been contested ever since. Confronted at an early age with abandonment and death, the novel's sensitive boy-hero grows to resemble a secular St Teresa of Ávila, gradually retiring from the world, before finally shunning society altogether by running away to sea. At the end of the novel, having lapsed briefly into normality only to lose the love of his life in a peculiar traffic accident, he achieves a new level of spirituality, which readers may find unconvincing. The author himself dismissed the second, seafaring half of the work as a Hollywoodesque aberration, but consistently defended volume one, and even toyed with the idea of rewriting volume two to a similar standard. ${ }^{1}$

Critics themselves have given various interpretations of this intriguing work. Randolph Pope notes an affinity with other emergent Spanish novels of the period, notably Carmen Laforet's Nada (1945): with these it shares a 'mirada retrospectiva' (Pope), a sense of incarceration and of primal marginalization, as well as the foregrounding of a sensitive individual against a nullified past. Yaw Agawu-Kakraba (1996) argues that Pedro's rejection of his stultifying quest for autonomy is a demythifying allegory of Franco's imposition of economic self-sufficiency (autarchy) during the 1940s. ${ }^{2}$ More recently, Ramón Buckley, noting that Pedro strives to negotiate his plight single-handedly, has suggested that the novel evokes the existentialist crisis and radical moral solitude of a generation of alienated European 
writers in the post-War period (2012: 34). The present study is less inclined to take the hero's lofty pronouncements on mortality at face value and instead highlights his sense of familial void, thereby contending that the tactic of withdrawal stems from complex privacies relating to orphanhood. In so doing, it argues that the novel is a more subtle literary work than has thus far been acknowledged by its commentators.

It could be argued that what existing approaches to this novel have in common is a move to encapsulate it within a single authorial utterance executed according to a principle of ideological unity. Such an approach befits some authors, but is perhaps less successful in elucidating the work of Delibes. Indeed, Buckley himself notes that, when creatively disposed, Delibes often deviated from expressly-held viewsthereby, for example, critiquing the encroachment of modernity upon traditional village life in Las ratas (1962) while, as a journalist, he had explicitly campaigned for rural modernization (Buckley 2012: 87-88). Such a tendency was potentially even more pronounced in a first novel. Furthermore, Delibes's political identity evolved over the years, growing steadily more liberal, oppositional, secular and eco-critical, so that bringing the early author into alignment with his later work is no straightforward matter. ${ }^{3}$ Thus, to read La sombra del ciprés es alargada as an example of expressive realism is to run the risk of simplifying it, for, despite Pedro's frank homilies on death, the work's underlying psychological energies are conveyed in evasive and circuitous ways. Accordingly, the primary anxieties caused by the orphanhood of Pedro and of his alter ego, Alfredo, reach the reader in a polyphonic, or multi-voiced, form.

Polyphony, as described by Mikhail Bakhtin (1984), is a happy consequence of effective novel-writing, and it is a feature of Delibes's best work. In allowing characters to speak for themselves, Delibes tends to dramatize ideological frictions which linger in the reader's mind in a less than fully assimilable form, even when the 
author's perspective is broadly evident or a work exhibits a high degree of aesthetic coherence. Intriguingly, the polyphony in La sombra del ciprés es alargada emanates from the narrator himself. Despite the strength of his resolve, Pedro relates the story of his life in an inchoate way, using a blend of voices which cannot comfortably be arranged into a single overarching discourse. This dispersal, in which competing claims upon the truth are represented, is especially noticeable in the first volume, where the perspective of the narrator's younger self dominates, even to the extent of countermanding that of the mature narrator. Here, the first-person narrative is marked by an unsettling blend of sententiousness and wavering; the distinction between what was thought then and what is being thought now becomes blurred. The narrator's Proustian alertness and receptivity to all fleeting mental phenomena turns out to be at odds with the supposition that decisive moral progress has since been made. Rather than resolve his former wrong-headedness, the mature Pedro often appears to be recreating states of blindness formerly experienced by his younger self. In re-laying the emotional and intellectual habitat of his youth, an unbidden sense of agnosticism starts to infiltrate the work. It is this hesitancy, perhaps, which gives volume one its ring of authenticity and which was lost in the sequel when the older Pedro proceeds to adopt a more thesis-like approach to his early experiences. ${ }^{4}$ In volume one Delibes does not adjudicate on whether the reader should take the narrator's typically solemn remarks to heart, or instead abjure them as philosophically immature. In this way, the significance of a remark or incident will often remain uncertain: does the cold pure air of Ávila kill Alfonso or cure him? Did Pedro provoke the onset of his friend's illness by taking him on a nocturnal journey into a cold and lifeless city, or is he the deceased Alfredo's sole champion and protector? 
So it is, in volume one, that, having been deposited in a boarding school in Ávila by an uncle who subsequently pays him only a lightning visit, a siblingless orphan of parents he never knew, and of whom he knows nothing, Pedro is so affected by the death of his soul mate Alfredo (his only co-boarder) that he elevates his tutor's prophylactic doctrine of dispassion to a universal principle of 'voluntary selfdetachment' (Díaz 1971: 41). The pattern is repeated, with more ambiguous moral consequences, in volume two, at the end of which Pedro loses his pregnant wife, Jane, in a freak (artistically infelicitous) accident. Whereas falling in love with Jane on the high seas had encouraged Pedro to reject the lugubrious philosophy of desasimiento, her loss provokes a further shift in outlook which has been variously interpreted by critics as a regression to - and vindication of - his previous strategy or, alternatively, a progression to a more balanced way of life. ${ }^{5}$ Since he is the ostensible source of the philosophy of desasimiento, which comes to dominate and distort Pedro's worldview, Don Mateo Lesmes, schoolteacher and quasi-father figure, tends to be singled out by commentators as the villain of the piece. It is not immediately apparent, however, whether his influence will be a force for good or ill. After all, though it is at odds with the more existential outlook of the modern world, the cultivation of detachment in the face of suffering and death is a timeless aspiration, present, for example, in the ancient Greek pursuit of ataraxia (serenity, or impassivity) and apatheia (equanimity), in Buddhism's intuition that suffering is attendant upon unskillful desire, as well as in the Schopenhaurian denial of the will. ${ }^{6}$ Such disinvolvement may be viewed as an apprenticeship to ethical re-engagement with the world. Hence, in Schopenhauer, it prepares the ground for empathy and compassion. So too in Unamuno, as Agawu-Kakraba reminds us, death-consciousness impels the individual towards others so that intersubjectivity will form the basis of self-realization (1996: 62-63). ${ }^{7}$ Moreover, despite Lesmes's 'mezquinos horizontes' (2002: 17) and 
romanticization of pre-modern Ávila, as conveyed by his veneration of the local hornacina — a running reference — with its depiction of victors and vanquished from bygone centuries, he is a more worldly character than his ascetic pronouncements might suggest. To begin with, he is portrayed as merely austere, frugal and limited. He delivers his first philosophical homily, following his boarders' initial examination successes, in the guise of a warning against overweening ambition; he urges his charges to be temperate and 'quedarse en poco' (49). This unremarkable formula is repeated soon afterwards in more portentous surroundings at Cuatro Postes (61), before a panorama of confining medieval walls. Although his pupils regard Lesmes as the embodiment of Ávila, a city associated with the mysticism of St Teresa (Alfredo remarks that 'Don Mateo parece hijo de las piedras de Ávila' (53)), they receive his words more secularly than spiritually. Pedro goes on to over-rationalize the 'apotegma mezquino' (141) of disinvolvement, inflating it to proportions far larger than those it assumes in the life of its originator, who is, after all, a married man of the world and an integrated member of Avilan society. Indeed, in the final chapter of volume one, the teacher 'aparentaba haberse olvidado de [su punto de vista frente a la vida]' (141). Pedro's appropriation and extension of the discourse of desasimiento seems to arise more from self-suggestion than intellectual perversion. His embrace of misanthropy cannot be traced back to Lesmes in any simple causal way.

Hence, Lesmes is a more multi-faceted figure than has been acknowledged by critics. (He is not an unusual Delibean creation: complexity is common among this author's villains.) Although the Lesmes household is emotionally and intellectually restricted, as shown by the wooden pedagogy, lack of soft furnishings the 'expansiones nocturnas' (21) of Doña Gregoria and her daughter, Martina, who vocalize in their sleep, and by Gregoria's hostility towards the free-spirited Regatillo sisters, it is not especially repressive, and never punitive. When, for instance, the 
pupils return from their nocturnal foray into Ávila they are met by an absence of adult censure. Lesmes dotes upon Martina-who forever seems to be chattering, playing, babbling and singing in the background of volume one - and is overwhelmed with fatherly concern for her when she is gravely ill for three weeks (24). Moreover, the family are notably biophilic, lavishing much affection on their pet dog, Fany, and goldfish. All members of the household, Pedro notes, experience the same 'fugas de [sus] almas hacia Fany, o los pececitos rojos' (48). When Alfredo is at death's door, his last request is to watch these fish being fed. At mealtimes, everyone feeds the dog, and Pedro is encouraged to join in. Therapeutically reminded of physiological realities, characters are comedically softened by such animal interactions, renewing their membership of the human family. Above all, Lesmes is quaintly fond of the goldfish, whom he feeds, to the fascination of all—adults, children and Fany — each night before retiring, as 'un festejo colectivo' (129). At Christmas, Lesmes incorporates them into the Nativity scene, the boys imagining them as whales (36). In celebration of his pupils' examination results, and thereby in a small way countermanding his sermon on the need to quedarse en poco, he includes his beloved goldfish in the celebrations by tipsily regaling them with puff pastry and, before his wife's timely intervention, attempting to fill their bowl with white wine. Later these fish are described by Pedro as 'sibaritas' (102). Thus, beneath Lesmes's bland philosophical veneer, Delibes allows us to catch a glimpse of a more subtle humanity at work. Significantly, the author ends the distressing episode in which Fany's paw is crushed under the wheel of a cart with a tableau of the teacher's trembling hand as he sprinkles crumbs into the goldfish bowl (64). The accident in question occurs when the cart, having almost knocked the teacher into the river, is angrily chased by his loyal dog. Although Lesmes seizes upon his pet's injury as proof of his doctrine of detachment, saying that 'si Fany hubiera nacido coja de dos patas hoy sentiría feliz de 
poder disponer de tres' (64), it seems to shake him just as deeply as it does his three young companions.

Had Delibes cast Fany as a human being, the reception of his novel might have been different. Agawu-Kakraba rightly notes that the animal is 'the only rallying point' and embodies the 'joy of living' (1996: 51), arguing that her example is an antidote to Lesmes's philosophy of non-involvement. Above all, however, she embodies an alternative model of disinvolvement: namely, a disposition towards the benefits of letting go and moving on, rather than of falling victim to Pedro's selfabnegatory death neurosis — his insistence on the need to 'tener siempre presentes a los muertos' (79) — with its attendant fantasy of self-containment. Attuned to the life instinct, Fany's spirits quickly rebound after her accident (entirely contrary to Lesmes's predictions, 'ahora era feliz con tres [patas] (75))' and, far from renouncing life, she relishes it all the more. This rival, far sunnier, version of desasimiento is of great importance but has been overlooked. To begin with, Pedro explicitly commends it: 'la facultad de desasimiento de la perrita era extraordinariamente elástica y muy desarrollada' (78). It is momentarily re-endorsed (although possibly ironically so) after the visit to the cemetery, when Pedro again seems to use the word desasir in a life-affirming way:

La realidad de la vida, despótica y hosca, no nos autorizaba a vivir con el muerto al hombro. Había que desprenderse de él, desasírnosle, para que su lastre no nos hiciese romper la armonía de la corriente vital. (87)

Fany gives a second lesson in resilience after the death of Alfredo, which she somehow intuits from afar, emitting desolate howls throughout the night of his passing. Initially distraught, her good spirits soon return. Now, however, her 
recuperation is resentfully associated by Pedro, at the onset of his alienated phase, with the 'glacial indiferencia' (125) shown by mourners at his friend's funeral. Indeed, even the goldfish, creatures whose attention-span is a byword for brevity, are scolded for such amnesia. But this is an alternative form of desasimiento which Pedro (as both character and, more ambiguously, narrator) is now rejecting:

Eso sí, la vida siguió para todos; para mí, que sentía, y para los demás que habían olvidado ya; para doña Leonor, para Fany y para los dos pececitos de la pecera verde. (136)

When, in a comical reprise of the snowy nocturnal expedition to Cuatro Postes which fatally aggravated Alfredo's illness, the goldfish die because an open window causes the water in their bowl to freeze solid we are being given a tongue-in-cheek commentary on Pedro's fundamental wrongheadedness. The implication is that the boys' earlier escape through a window into the dead of night was itself a life-denying frozen fantasy. A similar point is conveyed by the inclusion of animals in volume two when, owing to the vexatious proximity of stray dogs, Pedro is inhibited from opening his heart to Jane; in this way, the protagonist appears alienated from the web of life (192). In short, in volume one Pedro proves incapable of emulating Fany's exemplary coping; unlike her, his mourning is disordered ('Mis ojos estaban secos' (118)) and he finds it impossible to grieve and move on. His inability to let go of Alfredo is thus a prelude to the death-in-life syndrome of his early adulthood.

While commentators regard Pedro — taking him at his own estimation-as having been corrupted by Lesmes's advocacy of ascetic withdrawal (preaching which, 
as we have seen, Lesmes himself does not always practice), ${ }^{1}$ it would be more accurate to say that the pupil is predisposed towards adopting his tutor's morbid precepts for unstated psychological reasons of his own. These involve the rejecting into unconsciousness of negative feelings relating to orphanhood, emotions which are intensified by the death of Alfredo. His embrace of Lesmes's philosophy can be understood as a deflection which spares him full cognizance of the true source of his anguish. Initially, the novel is not much concerned with death: the primary issue is the protagonist's pervasive sense of abandonment, which is then reinforced by the shift to the loveless predicament of the school's newcomer. Alfredo suspects that his mother has left him there under pressure from her lover, who wishes to be rid of him. Even though Pedro has lost both parents, and indeed never knew them, the 'negra traición' (131) which befalls Alfredo makes his friend (Pedro believes) 'un huérfano en un grado aún más bajo que [él]' (46). However, more than a depiction of empathy and altruism, what is apparent here is a conflation of identities and a form of self-analysis by proxy. Alfredo, who is initially described as a fragile and colourless figurine, becomes the alter ego of the narrator-protagonist. Like Alfredo, Pedro feels that he is an 'estorbo' (16) to adults; in a disquieting scene in chapter three the mother's detested lover even mistakes him for Alfredo. A testily wordless confrontation ensues, which aptly conveys the mute engagement with orphanhood taking place in the course of the novel itself. Although Pedro regards himself as physically the more robust of the two friends, expressing concern about Alfredo's frailty and insisting that he weigh himself at the chemist's, in reality, and apparently unbeknownst to Pedro, they share a similar physique: ‘su peso era bastante normal (apenas si tenía cuatro kilos menos que yo)' (92). Conversely, Alfredo may be a weak and sickly child, yet he is also

\footnotetext{
${ }^{1}$ Thus Pedro asks himself: ‘ ¿Y no era el señor Lesmes quien había modelado a su gusto mi alma hipersensible?' (235).
} 
‘volcánico, abierto, impetuoso' (110); and Pedro, despite his greater physical selfconfidence, is 'introverso y pensador' (87). In fact, the two constitute a discreet dyad, displaying interchangeable traits and identities to a degree which the narrator fails to appreciate. Thus, for example, following the death of Alfredo, in a further case of mistaken identity, his grief-stricken mother embraces Pedro, addressing him as 'hijo' (120). Revolted, Pedro firmly rejects her advances, just as, earlier on, Alfredo had denied the very existence of the gesticulating señor outside the boarding school (34).

The lack of narratorial awareness is perhaps Delibes's way of using this dyad to decouple the cerebral Pedro from his unconscious energies. Pedro is aware of the 'historia común' (131) he shares with Alfredo, but deep knowledge of what unites and divides them is suppressed, even as he loyally sacrifices his own life to the memory of his deceased friend; his inability to grieve for the loss of his parents is transmuted into an inability to grieve healthily for the loss of his closest friend. The doubling up of Pedro is thus a supple device, allowing the author to articulate his hero's plight in artful ways which are partially invisible to the narrator himself. The extent of the similarity between the boys is both underdetermined (Pedro resembles Alfredo more than he chooses to admit since Pedro, too, has suffered traumatic parental abandonment) and overdetermined (the resemblance is weaker than he claims, for, unlike his friend, Pedro is not incurably ill). While Pedro wishes to emphasise the strength of their alliance, referring to 'nuestra orfandad' (93) and to the 'acercamiento creciente de nuestros espíritus' (47-48), Alfredo's outlook sometimes clashes tellingly with his own. Thus, behind his tutor's back, Alfredo will straightforwardly mock Lesmes’s philosophy ('¡iestá trastornado! (84)); he detests the thought of being immured in Ávila and its history; and he harbours the very worldly ambition of one day leaving the city to become rich. In this sense Alfredo is on the side of Fany, Martina and la corriente vital. During the first of two key scenes at Cuatro Postes, as 
Lesmes delivers his speech on the need to 'quedarse en poco' (61), Martina and the dog are endearingly distracted, the former intent on building a small stone tower while the latter sniffs through some rubbish. Alfredo is even less receptive. However, what to Alfredo's ears is simply risible ('apenas podía contener la risa' (63)) for Pedro constitutes a life-changing epiphany: 'Súbitamente me contemplé como un ser que empieza a usar de la razón con lógica y clarividencia'. He continues:

Mas el codo de Alfredo contra mi muslo me hizo pensar que, pese a todo, también podría sonreír; o reír francamente a carcajadas hasta que el amargo pesimismo de nuestro maestro se deshiciese en la atmósfera como el humo.

Such covalency permeates the novel. Pedro constantly flickers between moral viewpoints and it is uncertain whether the cathartic laugher alluded to here is available to him then or even later on-at the moment of narration. On this occasion, superficially, his under-determined identification with Alfredo foreshadows the cheerier worldview he will adopt in volume two, once he has met Jane. However, the narrative situation is complex, for the reader is uncertain whether the supposedly right-headed narrator has entirely laughed off Lesmes's counsel, according to the example of his deceased friend, or whether it is Alfredo's reaction which should be treated as immature.

There are two visits to Cuatro Postes, the second of which is initiated by Pedro in an attempt to restore Alfredo's health and spirits after Alfredo's return from a seaside holiday with his mother which turned sour. The dream of restoring the family unit, in all its emotional integrity, which this holiday possibly represents, is rudely curtailed by the unexpected resurgence of el hombre, whereupon Alfredo suffers a 
relapse. In the text, the dreamed restoration and painful disillusionment belong, rather unexpectedly, to Pedro himself: such is his initial elation on behalf of his friend that he buys Alfredo's mother a bunch of roses, intending Martina to present them to her at the station. When he espies el hombre, however, he behaves like a jilted lover, commanding Martina to toss the flowers away, with the result that they are crushed, melodramatically, beneath the wheels of the train (95). More than an expression of solidarity with a close friend, the strength of his emotional response here is redolent of infantile libido. Thus, the reader suspects that Pedro's sense of himself as an unloved son is being subconsciously projected into the episode. The air of stony impassivity he cultivates as a young adult is belied by the intensity of his yearning, articulated in a disguised way, for a redemptive mother figure. Again, the reader is uncertain whether the adult narrator is aware of the implications of this oblique selfdramatization.

The ensuing escape to Cuatro Postes, on a snowy moonlit night on which Ávila is emptied of its modern citizenry, comes after a sharp compression of discourse time. It is made to seem like the next important life-event, transpiring several months after the above incident, yet in the very next chapter of the story (chapter XII). Initiated by Pedro (Alfredo seems merely a reluctant sidekick), the trip is inspired by Lesmes, who earlier remarked to visiting relatives that a moonlit Cuatro Postes would make made a fine vantage point from which to view the city (74). What the episode has in common with the rose-tossing incident described above is its mute articulation of the narrator's poignant aspiration to transcend orphanhood. According to legend, Cuatro Postes is where, as children, Saint Teresa and her brother, planning to leave the city to fight the Moors (a kind of voluntary orphanhood), were intercepted by their uncle and returned to the family home. Lesmes recounts the story during their first (daytime) visit (60). In this sense his pupil's subsequent visit is one of journeying 
into an oneiric space where child-like psychodramas of object-loss and reconnection can be played out. It is a covert way of filling the void of orphanhood. For Pedro, then as now, the excursion seems primarily to represent a sanctifying journey into Ávila's past, uncorrupted by 'modernas impurezas' (101). Although Pedro declares that when he listened to Lesmes's speech during their first visit to Cuatro Postes his childhood 'quedó atrás' (114), the reader notes that a place of epiphany and revitalization for the protagonist proves fatal to Alfredo - the friend he insists is his soul mate. Alfredo sickens dramatically during this involuntary journey and on returning to the school suffers a severe tubercular haemorrhage, a 'brusca decadencia' (105), which soon afterwards culminates in his death. Alfredo's demise seems to banish the idea of Ávila as a zone of stultification and entrapment; this, too, can now be rejected into unconsciousness by Pedro. And yet, prior to this point, an adversarial relationship between the orphans and the city was in evidence. They would frequently indulge in war games in which they assaulted the encircling walls (53), and there are continual references to Lesmes's beloved medieval niche near the school with its depiction of victors and vanquished. Even as he sickens, Alfredo persists in attacking the colossal enclosure with a stick (104) and, just after his death—yet before his revisionism sets in-Pedro likens his friend to one of the hornacina's beaten warriors (120). Yet Pedro, whether as character or narrator, is eclectic in his identifications and does not acknowledge his friend's distaste for this fantasy city into which he has attempted to lure him. It is true that, at death's door, Alfredo asserts that they had an excellent time at Cuatro Postes, but the reader suspects that he is ingratiating himself with his friend by telling him what he thinks he wishes to hear (114). In a sense it is what Pedro wishes to hear from himself, even as it weakens the life force within him.

A similarly revealing impasse occurs earlier in the novel during a visit to a cemetery where Lesmes and his companions happen to observe a funeral cortège for a 
deceased young woman; her callow husband passes by, overcome by a 'soplo gélido' (83). Needless to say, Lesmes seizes upon the opportunity to teach his youthful companions an impromptu lesson on the need to be ever mindful of death, a nugget which Pedro absorbs in a rather perverse way by resolving never to marry. Lesmes is attending the cemetery to visit his parents' graves, and this provokes a moment of turmoil in Pedro, who at first experiences 'un deseo vehemente' (81) to discover the identities and final resting places of his own parents, instantly followed by a countervailing impulse to crush any such urge: 'Renuncié fríamente al ansia que me embargaba' (81). Each of Pedro's reactions - the rejection of marriage and the spurning of parents - signals a desire for mastery over absence by engaging in pleasurable renunciation. Pedro's quandary is mirrored by that of Alfredo, who first spits in disgust at a trite rhyming epitaph engraved on the tombstone of a child named García, 'víctima de una terrible disentería' (81), but then self-therapeutically insists on being buried beside a pine, a tree associated throughout the novel with nurturing maternity. Once again, Pedro identifies with Alfredo, but he reflexively underestimates the scope of that resemblance. Together with examples of conventional mourning — such as those provided by Lesmes, and the young widower - the chapter shows orphans expressing on the one hand craving for parental figures and, on the other, a virulent rejection of adults verging on disgust.

Alfredo's attitude towards his mother is as volatile as any displayed by Pedro towards his own parents during the cemetery visit. In addition to wishing to wrest psychological possession of his mother from el hombre, Alfredo resents her negligence and tries to punish her for it, even to the point of wallowing masochistically in his own sickness. As Pedro observes: 'En el fondo creo que [Alfredo] no perdonaba a su madre su cruel postergación' (91). What Pedro is less clear-sighted about is his own postergación as narrator. His narrative draws 
psychological parallels which he fails to recognize. Thus, he unconsciously inherits Alfredo's unresolved tussle with his mother. As noted above, the latter, traumatized by her son's death, momentarily mistakes Pedro for Alfredo but, just as at the railway station or in his rejection of his own parents in the cemetery, the nauseated Pedro blocks her advances in an aggressively infantile manner. Shortly afterwards, she disappears for good and, rather like Alfredo luxuriating in illness in order to punish his mother, Pedro embarks upon a masochistic regime of lifelessness, becoming a version of the fragile figurine which his friend once resembled: transformed into a 'caricatura psicológica' (170) of himself, and existing like an ornamental ship trapped in a bottle (169). The desasimiento he exhibits in volume two of the novel arises, paradoxically, from a psychological inability to let go of Alfredo (and, by extension, of his own trauma). Only with the death and, as Pedro views it, parental betrayal of his alter ego (Alfredo), does the narrator fully yield to Lesmes's philosophy of stoic temperance, inflating it into an all-encompassing psychosexual system. In this way, ineffectual mourning, described by Pedro as an emotional numbing ('un acorchamiento' (119)), recycles the negligence of the now reviled parent-figure into an attack upon the self, yet the negligence is camouflaged as a form of therapy. The ensuing self-deadening withdrawal from life is eventually diagnosed by Jane as puerile maladaptation: 'Eres parecido a un niño' (204), she remarks.

In contrast to volume one, which is pointedly rooted in terms of place and history, the seascape of part two is an unbounded space producing sensory fusions of land and water in which colours lose their identities, merging into complex tonal washes (157). In this way, it seems the perfect environment for accommodating narcissistic projections and, in effect, is a version of the deserted, nocturnal Ávila, which proved so uncongenial to Alfredo's health. However, although he attempts to shun interpersonal realities by communing with the sublime in this way, Pedro is 
confronted with the repressed source of his malady in ever more insistent forms, such as when he witnesses the repulsive spectacle of a seagull feeding upon the body of a sailor who has been drowned after the torpedoing of his ship. ${ }^{8}$ The spectacle has no direct bearing on grief (Pedro does not know the victim), although it is of vital personal significance to him. Pedro's reaction is to build it into an abstraction about man's inhumanity to man; it signals, he feels, his mission to advocate on behalf of 'los derechos de los muertos' (167). Yet, at the same time, the intimately sereneeven womb-like - sensation he derived from voyaging over the oceans is lost: 'El mar ... [pasó] a ser un agente más de la muerte; un agente hipócrita, devastador' (166). The primal scene regarding the death of his double, Alfredo, is perhaps being recovered here; the spell of pleasurable withdrawal which he cast upon himself at that time, thinking it would enable him to cope with that death, is beginning to be broken. Pedro's humanitarian response to the sight of the corpse, while heartfelt and noble, can be regarded as a deflection of a psychosexual problem that only Jane will eventually help him to face and overcome.

One of the strongest indications that orphanhood-induced trauma, rather than indoctrination by Lesmes, is responsible for driving the boys' identity development is provided by the inclusion of the minor character, La Bruna, the gypsy entertainer, whom they both find captivating. Delibes hints that she constitutes a maternal substitute for the boys, since, when she finally deserts Ávila, Pedro remarks that 'Alfredo y yo comprobamos que con esta falta se intensificaba nuestra orfandad' (93). Reputedly, she had many babies in the course of her travels but cheerfully abandoned them all to villagers and townspeople along the way in order to protect her liberty, behaviour which, from Alfredo's perspective, could be said to resemble that of his mother, who, he feels, consigned him to a boarding school simply in order to pursue a love affair. Alfredo's favourite copla, which he requests obsessively, is a song about a 
woman who sequesters her step-son from the world by confining him to a chest (a kind of miniaturized Ávila) replete with bote '«pa» que hiciese sus... necesidades' (56). His gratifyingly anal fantasy (one is obliged to say) is that La Bruna will one day compose a copla about his own imprisonment in which his mother's lover will be suitably vilified. Feeling uncomfortable, Pedro attempts to laugh off his double's masochistic wishes, just as Alfredo laughs off the gloomy aphorisms of Lesmes, which Pedro finds so seductive. Nevertheless, there is symmetry in their predicaments. Pedro's entire narrative is a version of Alfredo's fantasy copla in which the villain of the piece is ostensibly Lesmes yet, more accurately, all those who selfishly ignore or exploit the dead. What the narrator fails to perceive is that his selfalignment with his dead friend construes Pedro himself as a victim of emotional betrayal and thus deserving of pity. Accordingly, his fantasy of voluptuous absorption into Ávila's past, or the boundless expanses of the sea, unintentionally correlates with Alfredo's pleasurably self-abnegating fixation upon La Bruna and the beloved copla.

The foregoing discussion has focused primarily on key sequences in volume one of La sombra del ciprés es alargada - especially those involving orphanhood and the doubling up of Alfredo and Pedro-in order to suggest that, notwithstanding existing explanations of the novel, the genesis of the hero's deadlock is intergenerational trauma. The silent void of Pedro's origins, and the sense of rupture it engenders, fuels the protagonist's obsession with death and detachment —as in the manner of someone striving to cut off his nose to spite his face. Paradoxically, an inability to frame his predicament and lay the ground for his own recovery by letting go of the dead stalls Pedro's maturation by persuading him to cling tenaciously to a bloodless philosophy of letting go - which is really a version of holding on for grim death. In this regard it is useful to compare La sombra del ciprés es alargada with Laforet's Nada. In a recent article on Nada, Caragh Wells (2012) has argued that the 
main symptom of its heroine's disordered mourning for her mother is a camouflaging of loss through aesthetic writing. Equivalent diversionary tactics are evident in Delibes's later novel, except that they take the form of philosophizing rather than of poetic prosing. The conceit of self-transcendence in Delibes's novel, embodied by the retrospective narration in the first person, does not go fully according to plan; the upgraded understanding afforded by the passage of time falls short. It can be easy to underestimate this novel's narratological complexity since, superficially, the work seems so traditional, apparently offering the reader unproblematic access to the truth. Narrated in hindsight by the main character, with an internal analysis of events, a swath of personal experience is surveyed and appraised. In practice, however, as the narrator begins to replay formative experiences, the moral viewpoint shifts osmotically to his younger self so that the two Pedros are convoluted, just as he and Alfredo are themselves ravelled together. The text is strewn with potential clues and admonitions regarding orphanhood yet they remain unassimilated. A fragmentation of the self, supposedly now a thing of the past, thus manifests itself in the narrator's present, a purported overseeing turns into a kind of oversight (a postergación or acorchamiento), and a subequent narration of events becomes quasi-simultaneousall of which goes to create an oddly dissonant reading experience. The fact that the narrator seems unaware of such imbrications gives his account a self-beguiling quality which makes the reader wary of his claims of enlightenment. The truth about Pedro's past turns out to be only partially recoverable. Similarly, the artistic debacle at the end of the story, where Pedro sublimates his grief over the loss of Jane into a Job-like acceptance of God's inscrutable ascendency, has the contrary effect of insinuating that Pedro's self-therapy remains fragile and incomplete. Such ambivalence is conveyed metaphorically by the entrancing beauty of the dead nocturnal city of Ávila, whose walls are both shielding and imprisoning, or the frail 'copos de nieve en su 
constante indecisión entre el cielo y la tierra' (35). The novel is not a static treatise, therefore, but infused with dynamic indecision.

Pedro makes telling observations about mortality and even Lesmes's precepts are not without merit if taken in moderation. However, like Andrea in Nada-a character who by her own reckoning has achieved closure yet whose psyche still seems fractured to the reader-Pedro is an unreliable witness to his own pathology and the self-administered cure remains in doubt because the reader senses that he has not got to the bottom of his own story. As unreconciled orphans, both narrators are in denial of the true sources of their suffering. In this sense, Nada and La sombra del ciprés es alargada are exceptionally nuanced evocations of inter-generational rupture in post-war Spain.

\section{Works Cited}

Agawu-Kakraba, Yaw B., 1996. Demythification in the Fiction of Miguel Delibes (New York: Peter Lang).

Bakhtin, Mikhail, 1984. Problems of Dostoevsky's Poetics (Minneapolis: Minneapolis University Press).

Buckley, Ramón, 2012. Miguel Delibes, una conciencia para el nuevo siglo: la biografía intelectual de un gran clásico popular (Barcelona: Destino). 
Delibes, Miguel, 1969. La sombra del ciprés es alargada, 2a ed. (Barcelona: Destino).

Delibes, Miguel, 1962. Las ratas (Barcelona: Destino).

Delibes, Miguel, 'Autocrítica', in Delibes, Miguel, 1996. He dicho (Barcelona: Destino), pp. 96-99.

Eagleton, Terry, 2004. After Theory (St Ives: Penguin).

Gazarian Gautier, Marie-Lise, 1991. Interviews with Spanish Writers (Elmwood Park, Illinois: Dalkey Archive Press).

García Domínguez, Ramón, 2005. El quiosco de los helados: Miguel Delibes de cerca (Barcelona: Destino).

Díaz, Janet, 1971. Miguel Delibes (New York: Twayne).

Hart, Stephen, 1990. 'La Mort, la prédestination el le symbolisme des images dans "La sombra del ciprés es alargada" de Miguel Delibes', Imprévue, 2: 7-26.

Laforet, Carmen 1944. Nada (Barcelona: Destino).

Pope, Randolph D., 1984. Novela de emergencia: España 1939-1954 (Madrid: Sociedad General Española de Librería). 
Umbral, Francisco, 1970. Miguel Delibes (Madrid: Ediciones y Publicaciones

Españolas).

Wells, Caragh, 2012. "'Su larga trenza de pelo negro": The Phenomenon of

Disordered Mourning in Carmen Laforet's Nada', The Modern Language Review, 107:

1123-1140.

\footnotetext{
${ }^{1}$ In 1995 he wrote: 'rechazo [. . .] la segunda parte del libro, un pastiche cinematográfico del Hollywood más convencional de los años cuarenta que nada añade a la tesis del argumento' (Delibes 1996: 98). In the end, he says, he decided against a rewrite (Delibes 1996: 99).

${ }^{2}$ However, Francisco Umbral regards Delibes's first novel as 'pre-política' (1970: 46). Delibes himself stated that the novel sprang from a lifelong obsession with death. Newly married and with his wife expecting their first child, he was also extremely conscious of the fragility of human happiness (García Domínguez 2005: 118).

${ }^{3}$ In 1991 Delibes agreed that his first novel was informed by strong religious faith, but that such faith had subsequently weakened: 'I must emphasize that my religious sentiments right now are dominated by doubt and concern' (Gazarian Gautier 1991: 124).

${ }^{4}$ In 1970 Delibes said of his first novel that 'le sobra toda la segunda mitad. Con una poda despiadada de todas estas páginas, quedaría un librito que tendría un acento de plena veracidad, puesto que el frío de Ávila y el frío del corazón de este niño herido por la muerte de su amigo me parecen auténticos. Yo creo que es lo único auténtico de la novela'. Quoted in García Domínguez (2005: 145).

${ }^{5}$ Thus Díaz argues that his wife's death teaches Pedro 'that it was a mistake to have forsaken his philosophy' (Díaz: 43); Agawu-Kakraba contends that at the end of the novel 'Pedro's outlook as a whole is positive' (1996: 61); Hart argues that the novel is fundamentally Catholic —indeed scholastic - in outlook, apart from the presence of counterbalancing symbols of predestination, of which Jane's death is an example.

${ }^{6}$ Moreover, as Terry Eagleton has observed, the problem of death transcends culturalist forms of analysis: 'It is our perishing, not our bestowals of meaning, which is necessary' (2004: 163).

${ }^{7}$ Delibes himself regarded Unamuno's obsession with death as ego-centric (Gazarian Gautier: 124).

${ }^{8}$ Although unnamed, the conflict in question must be the First World War. There is a reference to the first edition of $A B C$, initially a weekly publication, which appeared in 1903 (Delibes 2002: 86); and to the Battle of Port Arthur (which took place in 1904) during the Russo-Japanese War (Delibes 2002: 120). The First World War fits this time frame.
} 